J. EDUCATIONAL COMPUTING RESEARCH, Vol. 37(1) 19-40, 2007

\title{
BEING THE SAME ISN'T ENOUGH: IMPACT OF MALE AND FEMALE MENTORS ON COMPUTER SELF-EFFICACY OF COLLEGE STUDENTS IN IT-RELATED FIELDS*
}

\author{
DEBBIE GOH \\ CHRISTINE OGAN \\ MANJU AHUJA \\ SUSAN C. HERRING \\ JEAN C. ROBINSON \\ Indiana University
}

\begin{abstract}
This study investigates the relationship between computer self-efficacy, mentoring, and the gender of mentors and students. The decline of women in IT-related programs of U.S. universities has led scholars to suggest that making more female faculty mentors available could raise female students' computer self-efficacy. This could address women's computational reticence and encourage more women to enter and remain in the programs. A survey of students from IT-related programs in five U.S. universities shows that extent of mentoring received, gender of students, and time students spent on computers as teenagers were significant predictors of computer self-efficacy. Extent of mentoring, gender of students, and gender of mentors have significant main effects on computer self-efficacy. Students with male mentors reported significantly higher computer self-efficacy while students with female mentors reported lower computer self-efficacy. Female students with no mentors reported the lowest level of computer self-efficacy.
\end{abstract}

*This study was funded by a National Science Foundation IT Workforce Grant \#0305859, "Toward Gender Equitable Outcomes in Higher Education: Beyond Computer Science." 


\section{INTRODUCTION}

Despite warnings and programs guarding against a decline of women in information technology over the past decade (Camp, 1997; Pfleeger \& Mertz, 1995; Spertus, 1991), recent reports continue to bemoan women's dwindling share in the IT workforce and IT-related college programs (Bolan, 2000; Information Technology Association of America, 2005; MacInnis, 2003). Stereotypes of women's roles and abilities in IT, an overtly masculine environment that is insensitive or unfriendly to women workers, sexual harassment and discrimination create a glass ceiling that impedes women's advancement in the field, resulting in a shrinking pipeline in academia and industry (Frenkel, 1990; Herring, Ogan, Ahuja, \& Robinson, 2006; Margolis, Fisher, \& Miller, 1999; Pearl et al., 1990; Spertus, 1991). These existing biases toward women in computing presumably contribute to lower self-esteem and self-efficacy (Klawe \& Leveson, 1995), inevitably making women less willing to join or remain in computer science. One way to counter this, scholars and practitioners suggest, is to engage mentors and role models, especially women mentors, to play an integral part in the professional development of women in IT (Ahuja, 2002; Compeau \& Higgins, 1995; Pfleeger \& Mertz, 1995; Noe, 1988a; Pearl et al., 1990; Spertus, 1991). They argue that women role models in IT can help overcome stereotypes that delimit computer science to a man's field where women are unlikely to succeed. More importantly, through the sharing of experiences and advice on how to navigate in a male-dominated environment, a female mentor or role model can improve a student's self-efficacy, resulting in greater determination and more strength to persevere and succeed.

Role modeling, a manifestation of mentoring (Kram, 1984; Scandura, 1992; Weaver \& Chelladurai, 1999), serves as an effective tool for promoting selfefficacy as the benefits very closely relate to a person's self-confidence and self-efficacy (Bandura, 1997, 1999). People's self-efficacy_belief in their abilities to accomplish certain tasks - will determine whether or not certain behavior or performance will be attempted, the amount of effort the individual will contribute to the behavior, and how long the behavior will be sustained when obstacles are encountered (Bandura, 1977). Numerous studies have found positive relationships between mentoring and students' self-efficacy (Clark, Harden, \& Johnson, 2000; Dreher \& Ash, 1990; Kram, 1984). Researchers have also found significant relationships between women's sense of comfort and selfefficacy with computers and their decision to enroll in IT programs (Ahuja, Ogan, Herring, \& Robinson, 2006; Bernstein, 1991; Lips \& Temple, 1990; Miura, 1986). There is, however, a lack of empirical evidence that connects the relationship between mentoring and computer self-efficacy. There is also no recorded evidence on how gender of mentors influence computer self-efficacy of students despite an unflagging focus over the past two decades on mentoring to attract and retain women in IT-related programs. As women continue to be underrepresented in IT, it is important that we understand the interplay between mentoring and 
computer self-efficacy of women in IT to enable us to better address computational reticence among women. Underlying this study's focus is the question of whether having same sex mentors enhances students' computer self-efficacy.

In this study, we aim to establish the relationship between gender, mentoring, and computer self-efficacy among students in IT-related college programs. We first seek to establish the predictors of computer self-efficacy, contributing to the body of knowledge on factors influencing computer self-efficacy. We then determine the relationship between the extent of mentoring students received and their computer self-efficacy. We also determine the role of similar gender in mentoring and students' computer self-efficacy, and compare differences between male and female students with male and female mentors.

\section{THEORETICAL DEVELOPMENT}

\section{Computer Self-Efficacy and Gender}

Self-efficacy is a dimension of Albert Bandura's social cognitive theory and refers to people's beliefs or expectations about their ability to accomplish certain tasks or demonstrate certain behaviors successfully (Bandura, 1977). People's self-efficacy contributes significantly to their motivation level and performance on a task (Bandura, 2001). It affects what they choose to do, how much effort they put on given activities, and how long they persevere at these activities (Bandura, 1977, 1982, 1986). Self-efficacy is influenced by task accomplishments, comparisons with others engaged in similar or parallel tasks, feedback and persuasion from significant people, and the individual's physiological and affective states (Bandura, 1997). Successes build a robust belief in one's personal efficacy while failures undermine it, so success in performing a task produces stronger and more generalized efficacy compared to the other sources of selfefficacy (Bandura, 1997).

Numerous studies have drawn on Bandura's concept of self-efficacy to measure computer self-efficacy. Compeau and Higgins (1995) defined computer selfefficacy as "a judgment of one's capability to use a computer" (p. 192) to perform computing tasks. Those with higher computer self-efficacy are more likely to believe in their abilities to accomplish more difficult computer tasks. Their study of business workers' attitude toward using a generic computer program found that individuals with higher self-efficacy enjoyed using computers more, had less computer anxiety, expected to perform their jobs more efficiently and effectively, and expected rewards such as raises, promotions and praise for their performance (Compeau \& Higgins, 1999).

Cassidy and Eachus (2002) examined self-efficacy beliefs in relation to computer use experience and familiarity with a range of computer programs. Their study of university students found that men reported significantly higher computer self-efficacy than women, and were more experienced and more familiar 
with more computer programs. Their study also found that similarities in computer training did not predict computer self-efficacy, as men continued to report higher self-efficacy than women, even with training. Burton's (1987) study of doctoral students at Carnegie-Mellon's computer science department found that while male and female students exhibited comparable performance quality in their studies, female students felt less comfortable, confident, and successful than the males. Bernstein (1991) has argued that differences between men and women's computer self-efficacy may contribute to women's lower level of achievement in computing. She found that for women to excel in computing, they needed to be more comfortable and to have positive experiences. Alden (1987) suggests that people who doubt their efficacy are more likely to view repeated successes as products of laborious effort than as evidence of their own capability, while those who are more self-assured believe even more highly in their capabilities following similar successes.

These studies support others that have found that men tend to over-rate their computing abilities and women tend to underestimate theirs despite better actual performance (Beyer, 1990; Cuny \& Aspray, 2000; Widnall, 1988). Furthermore, the loss of self-esteem by women increased significantly as they advanced in their academic career while that of men decreased slightly (Pearl et al., 1990). This phenomenon leads scholars to search for factors that influence differences between computer self-efficacy in men and women (Bernstein, 1991; Beyer, 1990; Burton, 1987; Cassidy \& Eachus, 2002; Cuny \& Aspray, 2000; Pearl et al., 1990; Widnall, 1988).

\section{Mentoring and Women's Self-Efficacy}

To attract and retain women in computer science, Cuny and Aspray (2000) recommend that women in computer science be given mentors who will provide individual encouragement. Mentoring is "an intense developmental relationship of relatively long duration in which protégés receive a range of career and psychosocial help exclusively from this one manager" (Whitely, Dougherty, \& Dreher, 1991, p. 333). A mentor is an experienced, productive supervisor who relates well to a less-experienced employee and facilitates his or her personal development for the benefit of the individual as well as that of the organization (Kram, 1984).

Kram (1984) identifies two distinct functions of mentoring: career function and psychosocial function. The career function, which includes sponsorship, exposure and visibility, coaching, protection, and assignment of challenging work, helps protégés learn the ropes and prepare for advancement. Mentors in academe generally provide assistance and feedback with writing grant proposal and preparing manuscript, read drafts, advise on likely sources of funding, and collaborate directly with protégés on research projects (Montelone, Dyer, $\&$ Dolores, 2003). The psychosocial function, which includes role modeling, 
acceptance and confirmation, counseling, and friendship, enhances protégés' sense of competence, identity, and effectiveness in a professional role. Mentors would introduce and initiate the protégés in the customs, demands, and expectations of academic life, sharing their wisdom and knowledge, encouraging protégés in their work, and helping them form a sense of themselves as members of the profession (Spertus, 1991). Through such sponsorship, coaching, protecting, exposing, and providing of challenging work assignments, the confidence of the protégés emerge, leading to a growing sense of competence and identity of their roles, which enables them to navigate more effectively in the organization (Kram, 1983).

Mentors have proven in many situations to enhance the self-efficacy of female protégés. Riley and Wrench (1985) reported that women with mentors experienced greater job success and job satisfaction than women who did not have mentors. Reich (1986) also found that female executives and academicians who participated in mentoring programs reported greater self-confidence and an enhanced awareness of and use of their skills. Montelone et al.'s (2003) study of the effects of mentoring on female and minority faculty members found that recipients of mentoring reaped positive effects including extramural funding successes, and tenure and retention. Evaluation of the Computing Research Association's Distributed Mentor Project 2000, which arranged for female undergraduate students to do summer research with faculty members at their mentors' research institutions, revealed that most students reported a greater understanding of and preparation for graduate school and many reported being more committed to graduate studies (Harold, 2000).

\section{Mentor-Protégé Similarities and Self-Efficacy}

In addition to mentoring, women faculty in IT also serve as role models for female students to help overcome stereotypes of women in computing by countering the computational reticence (Cuny \& Aspray, 2000). Computational reticence, according to Turkle (1988), refers to women deliberately avoiding the computer because they perceive it as a personal and cultural symbol of what a woman is not-a macho, competitive, and sometimes violent and all-consuming "intimate machine." It is thus desirable for women to be exposed to female role models who serve as evidence that a successful career in IT is not only a possibility, but a normal and unremarkable option for women (Pearl et al., 1990). For students, "female faculty members prove, by their very existence, that Ph.D. degrees and faculty slots can be attained by women" (Pearl et al., 1990, p. 51).

According to Bandura (1997), self-efficacy appraisals are partly influenced by vicarious experiences mediated through modeled attainments. Modeling serves as an effective tool for promoting self-efficacy because seeing or visualizing people similar to themselves perform successfully typically raises observers' 
efficacy beliefs that they too possess the capabilities to master comparable activities. Modeling influences that convince people of their efficacy weaken the impact of direct failure experiences and sustain efforts that support performance in the face of repeated failure. Self-efficacy appraisals are often based on similarity to models in terms of personal characteristics that are assumed to be predictive of performance capabilities. The greater the assumed similarity, the more persuasive are the models' successes and failures. If people see the models as very different from themselves, their beliefs of personal efficacy are not much influenced by the models' behavior and the results they produce.

Bandura's role modeling theory has found some support in various studies examining the influence of race and gender of role models on their credibility and ability to instill stronger efficacy beliefs. Santos and Reigadas' (2002) survey of Latino students in a higher education mentoring program found that students reported mentors with similar ethnicity as themselves as being more supportive in furthering their personal and career development. The students also reported significantly greater program satisfaction than students with mentors from a different ethnicity. Johnson-Bailey and Cervero (2004) presented race, class, and gender struggles African American women protégés in academe encountered in mentoring relations with white, male faculty. Nonetheless, studies have presented conflicting results on the perceived importance of race in mentoring relationships. Protégés from minority groups reported in surveys that race was less important than what the mentor did in a mentoring relationship (Hickson, 2002; Tillman, 2001; Tsedal, Anglin, Sanchez, \& Ballou, 2002). Other studies also reported that attitude toward cross-race mentoring was more important than race itself in a mentoring relationship (Bowman, Kite, Branscombe, \& Williams, 1999; Johnson-Bailey \& Cervero, 2004; Thomas, 2001).

Mentors and protégés with similar gender, however, appear to be more supportive of this theory of homogeneity in effective mentoring. Larwood and Blackmore (1978) showed that men and women prefer interacting with members of the same sex in the work environment. People are more comfortable interacting with those who are similar to them (Dreher \& Ash, 1990). Thus, if mentoring is important to any worker, it may be more important for women as it could help them overcome advancement barriers (Kanter, 1977). A lack of female mentors will negatively influence women's career advancement in IT (Ahuja, 2002). One reason is that in a male-dominated environment, overt and subtle discrimination of female students cause their self-confidence, ability to perform, and career advancement to suffer (Frenkel, 1990). Noe (1998a) reasons that women may have negative beliefs regarding their success and this can cause them to avoid challenging assignments and to decrease their motivation to advance in the field. Mentoring, particularly when involving female mentors, may help develop women's self-efficacy because through these initiatives, independent judgment is encouraged and reinforcement and feedback are provided. Failor (1990) notes that female junior faculty who have access to senior female faculty adjust to their 
positions and establish research programs more quickly than those who do not. Women thus unsurprisingly sought out female faculty because they want a sympathetic mentor (Frenkel, 1990).

\section{Research Questions and Hypotheses}

The above discussion suggests relationships between computer self-efficacy, level of mentoring, and the gender of both mentors and students. We thus raise the following research question about mentoring and computer self-efficacy of college students in IT-related programs:

1. What is the relationship between the level of mentoring and computer self-efficacy of college students in IT-related programs?

We also propose the following hypotheses:

1. Students who report greater extent of mentoring are more likely to have higher computer self-efficacy.

2. Male students with male mentors have greater computer self-efficacy than male and female students with female mentors.

3. Female students with female mentors have greater computer self-efficacy than male and female students with male mentors.

4. Male students with male mentors have similar computer self-efficacy as female students with female mentors.

\section{METHOD}

Data for this study is obtained from a Web-based survey, "Toward Gender Equitable Outcomes in Higher Education: Beyond Computer Science," administered by Indiana University's Information Technology Work Force (Ogan, Robinson, Ahuja, \& Herring, 2006). The survey is part of a larger project that examines the experiences, attitudes, and outcomes of women and men in IT programs at five U.S. publicly-funded research institutions to find out whether more female-oriented ("women-friendly") disciplinary cultures would produce more women in IT-related programs who report better quality educational experience (Ahuja, Herring, Ogan, \& Robinson, 2004).

The survey was administered between March and April 2004 to a non-random sample of undergraduate and graduate students. The universities surveyed were Indiana University Bloomington, University of Buffalo (formerly SUNY Buffalo), University of Illinois at Urbana-Champaign, University of Michigan at Ann Arbor and Dearborn, and University of Washington. The universities were selected based on the minimum requirement of having a computer science unit and at least two other IT-related units. Preference was given to institutions with programs in instructional technology and/or informatics. Programs from which students were sampled were computer science, information systems, informatics, 
instructional systems technology, and library and information sciences. Majority of respondents were contacted via their university e-mail accounts. For privacy reasons, students in three departments were contacted through an administrator in their program via e-mail. As such, the total number of surveys administered and actual class sizes are unavailable. Response rates for the other programs ranged from $32 \%$ to $85 \%$. Of the 1,768 students who responded to the survey, $52.1 \%$ were male and $33.6 \%$ were female. About $14 \%$ of students did not respond to this question.

In developing their measure for computer self-efficacy, Compeau and Higgins (1995) identified three dimensions of computer self-efficacy: magnitude, which refers to the level of capability expected; strength, which refers to the level of confidence individuals have about their ability to perform computing tasks; and generalizability, which refers to belief in ability to perform competently across different situations with different computer systems and programs. They also defined computing tasks as more than the ability to perform specific actions such as turning on a computer or entering data in a computer spreadsheet. Instead, tasks refer to "jobs," or higher-level outcomes such as conducting data analysis with computer software. The Compeau-Higgins scale consisted of 10 items that measured respondents' judgment of their confidence to use computer software to complete a job. Such a definition of task, as Cassidy and Eachus (2002) pointed out, offers more meaningful and useful measure of computer self-efficacy as compared to measuring highly specific component tasks such as saving files or knowing how to use particular software packages, particularly given the uniformity of computer programs. Cassidy and Eachus (2002) developed a 30 -item scale to measure general computer self-efficacy in an adult student population. The scale, which scored high on unidimensionality, internal consistency, test-retest reliability, and construct validity, measured respondents' agreement/ disagreement on statements related to their feelings toward computers.

In developing the computer self-efficacy variable for this study, a correlation matrix was used to identify survey items about students' attitudes toward working with computers and computer programs to include in a factor analysis extracting self-efficacy constructs. The criteria for inclusion were the presence of several correlations greater than .30 and less than .90 . Eight items, which mirror selfefficacy items on both the Compeau-Higgins and Cassidy-Eachus scales, were selected for a principal component analysis to determine the possible number of factors measuring self-efficacy (Table 1).

A principle axis factor analysis was conducted using promax rotation to extract two factors. The eigenvalue of the first factor (3.5) outweighs that of the second factor (1.2) by almost three times. Correlation between the two factors are high $(r=.59)$ and loadings of items on the structure matrix are unclean and high (Table 2). The factor analysis provided sufficient support to assume unidimensionality in the items. The eight items were then computed to form a composite scale measuring computer self-efficacy. Internal consistency 
Table 1. Survey Items Measuring Computer Self-Efficacy

Computer self-efficacy measures

1. How appealing is the challenge of solving problems with components to you? (very appealing, somewhat appealing, not too appealing, not at all appealing)

2. How comfortable are you working with computers? (very comfortable, somewhat comfortable, not too comfortable, not at all comfortable)

3. How would you rate your programming skills compared to other students in your major? (much better, somewhat better, about the same, somewhat worse, much worse)

3. How comfortable do you feel trying new things on the computer? (very comfortable, somewhat comfortable, not too comfortable, not at all comfortable)

4. When there is a problem with a computer program that you can't immediately solve, how likely is it that you will stick with it until you have the answer? (very likely, somewhat likely, not too likely, not at all likely)

5. How easily do you learn computer languages? (very easily, fairly easily, not too easily, not at all easily, not applicable)

6. How would you rate the grades you generally get in computer programming classes? (excellent, very good, good, fair, poor, not applicable)

7. would you rate your self-confidence when it comes to working with computers? (very confident, somewhat confident, not very confident, not at all confident)

of the scale was good (Cronbach's Alpha $=.80$ ). All the items had at least four responses each and these were recoded into a 4-point scale from 0 to 3 $(0=$ most negative attitude toward computers and $3=$ most positive toward computers). The resulting values ranged from 6 to 24 and this scale was recalibrated into a new scale that ranged from 1 to $19(1=$ very low self-efficacy and $19=$ very high self-efficacy).

A standard multiple regression was used to test the variables that predict students' computer self-efficacy. From the literature discussed above, we hypothesize that level of mentoring, gender of the students, and students' perception of their mentors' race are predictors of computer self-efficacy. Fifteen questions in the survey asked students about the types of mentoring they experienced (Table 3). The questions were drawn from the mentoring scale developed by Noe (1988b), which advanced the measurement of career and psychosocial mentoring functions 
Table 2. Structure Matrix of Factor Loadings on Computer Self-Efficacy Items

\begin{tabular}{lcc}
\hline Computer self-efficacy measures & Factor 1 & Factor 2 \\
\hline $\begin{array}{l}\text { How would you rate your self-confidence when it } \\
\text { comes to working with computers? }\end{array}$ & .723 & .530 \\
How comfortable are you working with computers? & .700 & .433 \\
$\begin{array}{l}\text { How comfortable do you feel trying new things on } \\
\text { the computer? }\end{array}$ & .698 & .278 \\
$\begin{array}{l}\text { When there is a problem with a computer program } \\
\text { that you can't immediately solve, how likely is it that }\end{array}$ & .540 & .378 \\
you will stick with it until you have the answer? & & \\
How appealing is the challenge of solving problems & .499 & .365 \\
with computers to you? & & .784 \\
How easily do you learn computer languages? & .490 & .732 \\
$\begin{array}{l}\text { How would you rate your programming skills } \\
\text { compared to other students in your major? }\end{array}$ & .312 \\
$\begin{array}{l}\text { How would you rate your self-confidence when it } \\
\text { comes to working with computers? }\end{array}$ & & .612 \\
\hline
\end{tabular}

identified by Kram (1984). Each item refers to a specific mentoring activity and combined, they refer to overall extent of mentoring. Correlations between the 15 items were at least $.30(p<.01)$, except between items 12 and $3(r=2.98)$ and items 4 and $15(r=2.97)$. A principle axis factor extraction followed by promax rotation produced two factors of eigenvalues 6.93 and 1.07. Factor loadings on the structure matrix were unclean and high, and the correlation between the two factors is .73, indicating unidimensionality in the items (Table 4). The items were thus computed to form a composite scale measuring the extent of mentoring students experienced. Only mentoring activity with a male or female faculty is considered in this study as the interest is in evaluating the influence of faculty mentoring in IT programs. Summing the 15 mentoring items, a new scale ranging from 0 (no mentoring influence) to 15 (very high extent of mentoring influence) was formed. Cronbach's alpha for the scale is .92 .

Gender of students was coded as female (0) and male (1). Given the conflicting literature on race as a predictor on the success of mentoring, this study posits 
Table 3. Survey Items Measuring Mentoring

Mentoring: For each of the following situations, select the person most associated with the situations of your current program of studies:

1. Recommended you for challenging assignments that present opportunities to learn new skills.

2. Recommended you for assignments that helped you meet other students in your department or school.

3. Recommended you for assignments that involved personal contact with professors in other department.

4. Helped you finish assignments/tasks or meet deadlines that otherwise would have been difficult to complete.

5. Gone out of his/her way to promote your career interest.

6. Informed you about what is going on at higher levels in the schools or how external conditions are influencing the school.

7. Conveyed feelings of respect for you as an individual.

8. Conveyed empathy for the concerns and feelings you have discussed with him/her.

9. Encourage you to talk openly about anxiety and fears that detract from your studies.

10. Shared personal experiences relevant to your problems.

11. Shared history of his/her career with you.

12. Encouraged you to think about graduate school.

13. Served as a role model.

14. Displayed attitudes and values about the field similar to your own.

15. Recommended you for fellowships, scholarships, or internships.

that similar race will be a positive predictor of self-efficacy. Thus, a question that asked respondents to indicate their perception of their mentor's race/ethnicity was selected as an independent variable and recoded as $0=$ different race from me, 1 = don't know (assuming unawareness leads to neutral effect), and $2=$ same race as me.

Studies have found that past experience with computers can also influence computer self-efficacy (Hasan, 2003; Bernstein, 1991; Mcilroy, Sadler, \& Boojawon, 2007). Thus, when a student first used a computer and the time spent on computers when they were teenagers were included as independent variables. Data for the question, "When and where did you first start using computers?" 
Table 4. Structure Matrix of Factor Loadings on Mentoring Items

\begin{tabular}{|c|c|c|}
\hline Mentoring items & Factor 1 & Factor 2 \\
\hline Conveyed feelings of respect for you as an individual. & .755 & .558 \\
\hline Shared history of his/her career with you. & .730 & .518 \\
\hline $\begin{array}{l}\text { Conveyed empathy for the concerns and feelings } \\
\text { you have discussed with him/her. }\end{array}$ & .725 & .531 \\
\hline $\begin{array}{l}\text { Shared personal experiences relevant to your } \\
\text { problems. }\end{array}$ & .716 & .494 \\
\hline $\begin{array}{l}\text { Displayed attitudes and values about the field similar } \\
\text { to your own. }\end{array}$ & .715 & .529 \\
\hline Served as a role model. & .706 & .534 \\
\hline $\begin{array}{l}\text { Informed you about what is going on at higher levels } \\
\text { in the schools or how external conditions are } \\
\text { influencing the school. }\end{array}$ & .626 & .606 \\
\hline Gone out of his/her way to promote your career interest. & .616 & .581 \\
\hline $\begin{array}{l}\text { Encourage you to talk openly about anxiety and fears } \\
\text { that detract from your studies. }\end{array}$ & .597 & .491 \\
\hline Encouraged you to think about graduate school. & .571 & .474 \\
\hline $\begin{array}{l}\text { Recommended you for fellowships, scholarships, or } \\
\text { internships. }\end{array}$ & .563 & .525 \\
\hline $\begin{array}{l}\text { Recommended you for assignments that helped } \\
\text { you meet other students in your department } \\
\text { or school. }\end{array}$ & .616 & .785 \\
\hline $\begin{array}{l}\text { Recommended you for challenging assignments that } \\
\text { present opportunities to learn new skills. }\end{array}$ & .639 & .747 \\
\hline $\begin{array}{l}\text { Recommended you for assignments that involved } \\
\text { personal contact with professors in other department. }\end{array}$ & .473 & .656 \\
\hline $\begin{array}{l}\text { Helped you finish assignments/tasks or meet } \\
\text { deadlines that otherwise would have been difficult } \\
\text { to complete. }\end{array}$ & .496 & .549 \\
\hline
\end{tabular}


was recoded as $1=$ after secondary school (this includes those who began using the computers in college, at work, or at home, when the person had begun working or was in college), 2 = during secondary school, 3 = during elementary school, or 4 = before elementary school. The question, "Between the ages of 12 and 17, how much of your time was spent using a computer," was recoded as $0=$ none of my free time, $1=$ little of my free time, $2=$ some of my free time, $3=$ a lot of my free time, or $4=$ most of my free time.

As the academic and physical maturity of students can very likely influence their computer self-efficacy, age and class standings were included as control variables. Respondents were born between 1939 and 1986. At the time of the survey, they were aged been 18 and 65 years old. Some 264 cases (15\%) failed to indicate their year of birth. Students' class standings were coded as undergraduate level (1), master's level (2), and doctoral level (3).

Three independent variables, sex, age, and perception of mentor's race, had large numbers of missing values, and dummy variables were created, where $0=$ reported value and $1=$ missing value. A one-way analysis of variance was then used to test for differences in self-efficacy between the group that reported and the group that failed to report information on each of these variables. The ANOVA showed no significant differences between the groups. Thus, listwise deletion was used for subsequent statistical tests.

As this study seeks to determine predictors of students' computer self-efficacy, a standard multiple regression is used. The extent of mentoring received, gender of the students, students' age, students' class standings, when students first used computers, the time students spent on computers when they were teenagers, and students' perception of their mentors' race were entered simultaneously into the regression model.

To determine if extent of mentoring, gender of students, and gender of mentors influenced differences in students' computer self-efficacy, a three-way ANOVA was conducted. To determine if gender of faculty has any influence on students' computer self-efficacy, a variable - sex of mentors - was created from the 15 mentoring questions, where $0=$ no mentors, $1=$ male faculty mentors, $2=$ female faculty mentors, and $3=$ male and female faculty mentors.

\section{RESULTS}

Table 5 shows that, overall, the seven independent variables account for $13.6 \%$ of the variance in self-efficacy, $F(7,1167)=27.31, p<.001$. Only the sex of the student, extent of mentoring received, and time students spent on computers when they were teenagers were significant positive predictors of self-efficacy; i.e., students who are male, who received greater extent of mentoring, and who spent more time on computers as teenagers are more likely to report higher levels of self-efficacy. The standardized regression coefficients show that sex of a student is 
Table 5. Regression Analysis of Predictors of Self-Efficacy $(N=1175)$

\begin{tabular}{|c|c|c|c|c|c|}
\hline & B & SE & $\beta$ & $t$ & $\begin{array}{l}\text { Tolerance } \\
\text { level }\end{array}$ \\
\hline Extent of mentoring & .041 & .774 & $.056^{\star}$ & 1.94 & .891 \\
\hline Sex of student & 2.085 & 0.021 & $.279 * *$ & 9.833 & .912 \\
\hline Age of student & .011 & .019 & .021 & .572 & .538 \\
\hline Class standing & .847 & .147 & .186 & 5.757 & .538 \\
\hline When student started using computers & .189 & .147 & .047 & 1.287 & .548 \\
\hline $\begin{array}{l}\text { Time spent on computers between } \\
\text { ages } 12 \text { and } 17\end{array}$ & .449 & .112 & $.150 * \star$ & 4.000 & .522 \\
\hline Perception of mentor's race & .131 & .109 & .033 & 1.197 & .969 \\
\hline
\end{tabular}

$R^{2}=14.1$, Adjusted $R^{2}=13.6, p<.001$.

the strongest predictor of self-efficacy, followed by the time spent on computers, and then by extent of mentoring received ${ }^{1}$.

Table 6 shows the mean computer self-efficacy reported by male and female students receiving different extent of mentoring from male and/or female mentors. The three-way ANOVA shows that gender of students, gender of mentors, and extent of mentoring all had significant main effects on computer self-efficacy. Gender of students had the largest main effect, $F(1,1116)=48.96, p<.001$, followed by gender of mentors, $F(3,1116)=3.02, p<.05$, then by extent of mentoring, $F(15,1116)=1.77, p<.05$. None of the interaction effects were significant. Partial Eta squared for the corrected model is .184, indicating that the three independent variables contribute to about $18 \%$ of the variability in the level of self-efficacy of students.

In general, students who reported experiencing 0 to 7 mentoring activities reported lower self-efficacy than the overall mean $(M=13.98, S D=3.49)$. The results support hypothesis 1 , which posits that students who received greater extent of mentoring are more likely to report higher computer self-efficacy. Male students on average reported higher self-efficacy $(M=14.71, S D=3.25)$ than female students $(M=12.40, S D=3.47)$. Male students with male mentors also reported the highest self-efficacy score across the total sample $(M=15.09, S D=$ 3.17 ), supporting hypothesis 2 . Female students with female faculty, however,

\footnotetext{
${ }^{1}$ Age, when a student started using computers, and time spent on computers had large correlations $(r>.56)$ and low tolerance levels $(<.55)$, suggesting multicollinearity. However, regression with these variables entered in separate block neither resulted in large $R^{2}$ change not improved the significance of the variables.
} 


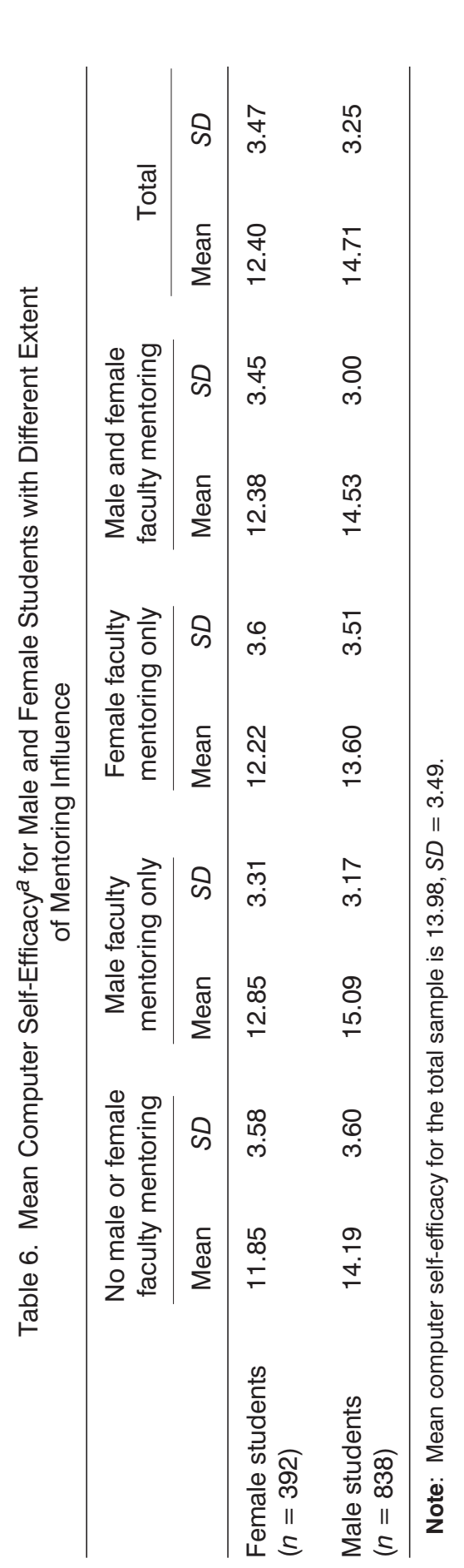


reported lower computer self-efficacy $(M=12.22, S D=3.60)$ than female students with either male mentors or both male and female mentors. Their self-efficacy score is also lower than male students with male mentors. Hypotheses 3 and 4 are thus not supported. Interestingly, male students with female mentors reported lower computer self-efficacy $(M=13.60, S D=3.51)$ than male students with no mentors, male mentors, or both male and female mentors. Women with no faculty mentoring reported the lowest computer self-efficacy $(M=11.85, S D=3.58)$.

As Levene's test of equality of variances was not significant, i.e., equal variances were assumed, post-hoc Tukey and Scheffe's tests were conducted to determine where the differences lay between the groups. Post-hoc tests show that students with only female mentors or only male mentors belonged to different subsets. The findings thus support the second hypothesis, but not hypotheses 3 and 4 .

\section{DISCUSSION}

Findings of this study indicate that gender, the extent of mentoring received, and the amount of time spent on computers as teenagers are significant predictors of computer self-efficacy of college students in IT programs. The analysis of variance further confirms that students who reported experiencing mentoring from faculty reported higher computer self-efficacy than those who did not. In addition, this study supports earlier studies that found that women report lower self-efficacy than men. This study also establishes that merely looking at the extent of mentoring does not sufficiently reveal more subtle influences on computer self-efficacy. By examining relationships between gender of mentors and gender of students, we found that students with male mentors overall had higher computer self-efficacy while those with female mentors tended to report lower levels of computer self-efficacy.

Computer self-efficacy has been established as an important factor for participation and perseverance in IT. Despite concerted efforts over the past decade to encourage women's presence in the IT-field, progress into the 21 st century does not seem to have improved computer self-efficacy of women in IT. Findings of this study suggest that the chronic decline in women's academic involvement in IT-related fields may be related to this inability to improve women's computer self-efficacy. Scholars, believing that exposure to female role models in IT will provide proof that women can be successful in the field, have proposed engaging female mentors to enhance women's computer self-efficacy. Our findings suggest that female mentors, to a small extent, can enhance women students' computer self-efficacy. However, women students with male mentors still reported higher self-efficacy, and male students with female mentors reported lower computer self-efficacy, which leads us to question whether women faculty were less effective than men in mentoring and influencing students' self-efficacy. 
We should be cautious about discrediting women as mentors. Ülkü-Steiner, Kurtz-Costes, and Kinlaw (2000) found that it was the presence of female faculty in a department and not the gender of the student's mentor that is most important for enhancing doctoral students' academic experience in male-dominated graduate programs. The number of women faculty mentors in the IT programs surveyed in this study is highly outnumbered by males. Of the 1,175 cases included in the analysis, only 108 cases had solely female mentors. The weak presence of female mentors may explain why female students continue to have less positive experience and lower self-efficacy.

Bandura (1997) proposed that self-efficacy can be increased or reduced by visualizing people similar to oneself as successful or unsuccessful. There are two ways this theory can explain the lower levels of self-efficacy among students with female mentors. First, stereotypes of women as less able to succeed in computer science may have prejudiced students' perception of the success or effectiveness of women faculty. Students with such preconceived notions of female faculty may not think female mentors are as effective in helping them through their programs of study. For female students with already low self-efficacy, such a perception likely further lowers their confidence. Second, female faculty may in fact be less successful than male faculty in these male-dominated programs. The 2004 National Study of Postsecondary Faculty found that men heavily outnumbered women in male-dominated fields such as engineering and the natural sciences, and that women represented a larger proportion of part-time than full-time faculty (Cataldi, Fahimi, Bradburn, \& Zimbler, 2005). It is also without contention there are more senior male faculty than female faculty. With seniority comes reputation, connection, and academic support that make male faculty more able to offer their protégés more opportunities for academic success in terms of research resources and connections with other faculty in the field. Thus, students with female mentors may not think of them as role models of success, compared to the more senior male faculty in the department.

Mentoring involves more than just classroom teaching. It involves career and psychosocial functions such as counseling, coaching in assignments, assisting with grant proposals, connecting protégés with other faculty, among others, as Kram (1988) and Montelone et al. (2003) highlighted. Mentoring in itself is a big responsibility. Women faculty may thus be less effective as mentors due to an overload of academic and non-academic responsibilities. With additional pressure to achieve tenure and respect in a male-dominated environment, women faculty may have to focus more on excelling in classroom teaching, research and service to the university and the profession. Women may also often find themselves appointed to various planning committees and service areas in the university or the profession as a means of diversifying representation. Furthermore, societal demands on women today in general remain the same as in the past, particularly in familial responsibilities. Pressures of marital and parental responsibilities tend to be greater for women faculty than male faculty as a higher 
percentage of women than men are engaged in dual career marriages (Gappa \& Leslie, 1993). Few senior women faculty in science at the Massachusetts Institute of Technology, for example, are married or have children as being first-rate scientists, to them, means giving total priority to work and having no outside interests and responsibilities (Bailyn, 2003). Thus, while successful faculty in science may be role models professionally, they are hardly good role models socially, mitigating the effect of enhancing self-efficacy in students.

Possibly the most important implication of this study is that IT-related programs that are committed to attracting and retaining women need to address deeply-seated stereotypes and praxis surrounding the roles of women in these departments. Harding (1998) warned that simply adding women in science and technology will not solve gender-related problems because conventional frameworks had been formulated in opposition to the feminine. Wajcman (1991) argues that equal opportunity recommendations ask women to exchange major aspects of their gender identity for a masculine version without prescribing a similar degendering process for men. Thus, in addition to increasing women faculty, IT-related departments need to work toward eliminating stereotypes of women - at both faculty and student levels - in the field. The departments also need to evaluate the environment in which women faculty are expected to work and the demands placed on them, and be willing to restructure these in ways that enable them to become productive and effective as researchers, instructors, mentors, and role models.

The present data do not offer insight into the environment in which mentoring activities occur. What roles the mentors played, how mentors and protégés select one another, and how their relationship developed are important aspects that need to be understood to evaluate the effectiveness of mentoring (Welch, 1996). Without understanding the context, it would be unjust to conclude that women mentors are not effective in raising students' self-efficacy. Future research thus needs to ask broader questions related to the ways the field of information technology can be reshaped so that women faculty can become effective mentors for students. There are many approaches and sociological considerations that must be made to address this problem of computational reticence. Simply having female mentors for female students is just not enough.

\section{REFERENCES}

Ahuja, M. (2002). Women in the information technology profession: A literature review, synthesis and research agenda. European Journal of Information Systems, 11(1), 20-34.

Ahuja, M., Herring, S. C., Ogan, C., \& Robinson, J. C. (2004). Exploring antecedents of gender equitable outcomes in IT higher education. Proceedings of the 2004 SIGMIS Conference on Computer Personnel Research: Careers, Culture, and Ethics in a Networked Environment, 120-123. 
Ahuja, M., Ogan, C., Herring, S. C., \& Robinson, J. C. (2006). Gender and career choice determinants in information systems professionals: A comparison with computer science. In F. Niederman \& T. Farrat (Eds.), IT workers: Human capital issues in a knowledge-based environment (pp. 279-304). Greenwich, CT: Information Age Publishing.

Alden, L. (1987). Attributional responses of anxious individuals to different patterns of social feedback: Nothing succeeds like improvement. Journal of Personality and Social Psychology, 52, 100-106.

Bailyn, L. (2003). Academic careers and gender equity: lessons learned from MIT. Gender, Work and Organization, 10(2), 137-153.

Bandura, A. (1977). Self-efficacy: Toward a unifying theory of behavioral change. Psychological Review, 84, 19-215.

Bandura, A. (1982). Self-efficacy mechanism in human agency. American Psychologist, $37,122-147$.

Bandura, A. (1986). Social foundations of thought and action: A social cognitive theory. Englewood Cliffs, NJ: Prentice Hall.

Bandura, A. (1997). Self-efficacy: The exercise of control. New York: W. H. Freeman and Company.

Bandura, A. (1999). Social cognitive theory of personality. In L. Pervin \& O. John (Eds.), Handbook of personality (pp. 154-196). New York: Guilford Press.

Bandura, A. (2001). Social cognitive theory: An agentic perspective. Annual Review of Psychology, 52, 1-26.

Bernstein, D. R. (1991). Comfort and experience with computing: Are they the same for women and men? SIGCSE Bulletin, 23(3), 57-60.

Beyer, S. (1990). Gender differences in the accuracy of self-evaluations of performance. Journal of Personality and Social Psychology, 29(5), 960-970.

Bolan, S. (2000). Women in IT on decline. Computing Canada, 26(22), 29.

Bowman, S. R., Kite, M. E., Branscombe, N. R., \& Williams, S. (1999). Developmental relationships of Black Americans in the academy. In A. J. Murrell, F. J. Crosby, \& R. J. Ely (Eds.), Mentoring dilemmas: Developmental relationships within multicultural organizations (pp. 21-46). Mahwah, NJ: Lawrence Erlbaum Associates.

Burton, M. D. (1987). Gender differences in professional socialization: A study of women and men becoming computer scientists (technical report). Pittsburgh, PA: Carnegie Mellon University, Committee on Social Science Research in Computing, Social and Decision Sciences Department.

Camp, T. (1997). The incredible shrinking pipeline. Communications of the ACM, 40(10), 103-110.

Cassidy, S., \& Eachus, S. (2002). Developing the computer user self-efficacy (CUSE) scale: Investigating the relationship between computer self-efficacy, gender and experience with computers. Journal of Educational Computing Research, 26(2), 133-153.

Cataldi, E. M., Fahimi, M., Bradburn, E. M., \& Zimbler, L. (2005). 2004 National Study of Postsecondary Faculty: Report on Faculty and Instructional Staff in Fall 2003. Retrieved July 22, 2005, from http://nces.ed.gov/pubs2005/2005172.pdf

Clark, R. A., Harden, S. L., \& Johnson, W. B. (2000). Mentor relationships in clinical psychology doctoral training: Results of a national survey. Teaching of Psychology, 27(4), 262-268. 
Compeau, D. R., \& Higgins, C. A. (1995). Computer self-efficacy: Development of a measure and initial test. MIS Quarterly, 19, 189-211.

Compeau, D. R., \& Higgins, C. A. (1999). Social cognitive theory and individual reactions to computing technology: A longitudinal study. MIS Quarterly, 23(2), $145-158$.

Cuny, J., \& Aspray, W. (2000). Recruitment and retention of women graduate students in computer science and engineering. Retrieved May 24, 2004, from http://www.cra.org/reports/r\&women.pdf.

Dreher, G. F., \& Ash, R. A. (1990). A comparative study of mentoring among men and women in managerial, professional, and technological positions. Journal of Applied Psychology, 75(5), 539-346.

Failor, B. (1990, Winter). The history of EYH. Math/Science Network Broadcast, 5.

Frenkel, K. A. (1990). Women and computing. Communications of the ACM, 33(11), 34-46.

Gappa, J., \& Leslie, D. (1993). The invisible faculty: Improving the status of part-timers in higher education. San Francisco: Jossey-Bass.

Harding, S. (1998). Is science multicultural? Postcolonialism, feminisms, and epistemologies. Bloomington: Indiana University Press.

Harold, M. J. (2000). Distributed mentor project: Evaluation of impact and experiences of participants. Retrieved May 24, 2004, from http://www.cra.org/activities/craw/reporots/sep00.pdf

Hasan, B. (2003). The influence of specific computer experiences on computer selfefficacy beliefs. Computers in Human Behavior, 19(3), 443-450.

Herring, S. C., Ogan, C., Ahuja, M., \& Robinson, J. C. (2006). Gender and the culture of computing in applied IT education. Retrieved October 15, 2006, from http://ella.slis.indiana.edu/ herring/gite.pdf.

Hickson, M. G. (2002). What role does the race of professors have on the retention of students attending historically black colleges and universities? Education, 123(1), 186-189.

Information Technology Association of America. (2005). Untapped talent: Diversity, competition and America's high tech future. Retrieved October 25, 2006, from http://www.itaa.org/eweb/upload/execsummdr05.pdf.

Johnson-Bailey, J., \& Cervero, R. M. (2004). Mentoring in black and white: The intricacies of cross-cultural mentoring. Mentoring and Tutoring, 12(1), 7-21.

Kanter, R. M. (1977). Men and women of the corporation. New York: Basic Books.

Klawe, M., \& Leveson, N. (1995). Women in computing: Where are we now? Communications of the ACM, 38(1), 29-35.

Kram, K. E. (1983). Phases of the mentor relationship. Academy of Management Journal, 26, 608-625.

Kram, K. E. (1984). Mentoring at work: Developmental relationships in organizational life. Glenview, IL: Scott, Foresman.

Kram, K. E. (1988). Mentoring at work: Developmental relationships in organizational life. Lanham, MD: University Press.

Larwood, L., \& Blackmore, J. (1978). Sex discrimination in manager selection: Testing predictions of the vertical dyad linkage model. Sex Roles, 4, 359-367.

Lips, H. M., \& Temple, L. (1990). Majoring in computer science: Causal models for women and men. Research in Higher Education, 31(1), 99-113. 
MacInnis, P. (2003). The gender gap. Computer Canada, 29(11), 26.

Margolis, J., Fisher, A., \& Miller, F. (1999, Winter). Caring about connections: Gender and computing. IEEE Technology \& Society Magazine, 18, 13-20.

Mcilroy, D., Sadler, C., \& Boojawon, N. (2007). Computer phobia and computer selfefficacy: Their association with undergraduates' use of university computer facilities. Computers in Human Behavior, 23(3), 1285-1299.

Miura, I. T. (1986). Computer self-efficacy: A factor in understanding gender differences in computer course enrollment. Paper presented at the Annual Meeting of the American Educational Research Association, San Francisco, CA, April 16-20, 1986.

Montelone, B. A., Dyer, R. A., \& Dolores, J. T. (2003). A mentoring program for female and minority faculty members in the sciences and engineering: Effectiveness and status after 9 years. Journal of Women and Minorities in Science and Engineering, 9(3\&4), 259-271.

Noe, R. A. (1988a). Women and mentoring: A review and research agenda. Academy of Management Review, 13(1), 65-78.

Noe, R. A. (1988b). An investigation of the determinants of successful assigned mentoring relationships. Personnel Psychology, 41(3), 457-479.

Ogan, C., Robinson, J. C., Ahuja, M., \& Herring, S. C. (2006). Gender differences among students in computer science and applied information technology. In W. Aspray \& J. McGrath Cohoon (Eds.), Women and information technology: Research on the reasons for under-representation (pp. 279-300). Cambridge: MIT Press.

Pearl, A., Pollack, M. E., Riskin, E., Thomas, B., Wolf, E., \& Wu, A. (1990). Becoming a computer scientist: A report by the ACM Committee on the status of women in computing science. Communications of the ACM, 33(11), 47-57.

Pfleeger, S. L., \& Mertz, N. (1995). Executive mentoring: What makes it work? Communications of the ACM, 38(1), 63-75.

Reich, M. H. (1986). The mentor connection. Personnel, 63(2), 50-62.

Riley, S., \& Wrench, D. (1985). Mentoring among women lawyers. Journal of Applied Social Psychology, 15, 374-386.

Santos, S., \& Reigadas, E. T. (2002). Latinos in higher education: An evaluation of a university faculty mentoring program. Journal of Hispanic Higher Education, 1(1), 40-51.

Scandura, T. A. (1992). Mentorship and career mobility: An empirical investigation. Journal of Organizational Behavior, 13, 169-174.

Spertus, E. (1991). Why are there so few female computer scientists? Retrieved February 22, 2004, http://people.mills.edu/spertus/Gender/pap/pap/html.

Thomas, D. A. (2001). The truth about mentoring minorities: Race matters. Harvard Business Review, 79(4), 98-107.

Tillman, L. C. (2001). Mentoring African American faculty in predominantly white institutions. Research in Higher Education, 42(3), 295-325.

Tsedal, B., Anglin, M., Sanchez, W., \& Ballou, M. (2002). Mentoring and relational mutuality: Proteges' perspectives. Journal of Humanistic Counseling, Education \& Development, 41(1), 87-102.

Turkle, S. (1988). Computational reticence: Why women fear the intimate machine. In C. Kramarae (Ed.), Technology and women's voices: Keeping in touch (pp. 41-61). New York: Routledge. 
40 / GOH ET AL.

Ülkü-Steiner, B., Kurtz-Costes, B., \& Kinlaw, C. R. (2000). Doctoral student experiences in gender-balanced and male-dominated graduate programs. Journal of Educational Psychology, 92(2), 296-307.

Wajcman, J. (1991). Feminism confronts technology. University Park, PA: The Pennsylvania State University Press.

Weaver, M. A., \& Chelladurai, P. (1999). A mentoring model for management in sport and physical education. Quest, 51, 24-38.

Welch, O. M. (1996). An examination of effective mentoring models in the academy. Paper presented at the Annual Meeting of the American Educational Research Association, New York, April 8-13, 1996.

Whitely, W., Dougherty, T. W., \& Dreher, G. F. (1991). Relationship of career mentoring and socioeconomic origin to managers and professionals early career progress. Academy of Management Journal, 34(2), 331-351.

Widnall, S. E. (1988). AAAS presidential lecture: Voices from the pipeline. Science, 241, 1740-1745.

Direct reprint requests to:

Dr. Debbie Goh

School of Journalism

Indiana University Bloomington

904 E. Seventh Street

Bloomington, IN 47405

e-mail: dgoh@indiana.edu 